\title{
Biological Effects of a Sulfated-Polysaccharide Isolated from the Marine Red Algae Champia feldmannii
}

\author{
Ana Maria Sampaio Assreuy, ${ }^{* a}$ Daniel Magalhães Gomes, ${ }^{a}$ Michelle Soares Josino da Silva, ${ }^{a}$ \\ Valeska Martins Torres, ${ }^{b}$ Rômmulo Celly Lima SiqueIrA, ${ }^{a}$ Alana de Freitas PIres, ${ }^{a}$ \\ David Neil CRIDDLE, ${ }^{c}$ Nylane Maria Nunes de Alencar, ${ }^{d}$ Benildo Sousa CAVAdA, ${ }^{e}$ \\ Alexandre Holanda SAMPAIO, ${ }^{b}$ and Wladimir Ronald Lobo FARIAS ${ }^{b}$ \\ ${ }^{a}$ Instituto Superior de Ciências Biomédicas, Universidade Estadual do Ceará; Av. Paranjana 1700, 60740-000, Fortaleza- \\ Ceará-Brasil: ${ }^{b}$ Departamento de Engenharia de Pesca, Universidade Federal do Ceará; Av Mister Hull s/n Bloco 827, \\ 60.356-000, Fortaleza-Ceará-Brasil: ${ }^{c}$ MRC Secretory Control Research Group, The Physiological Laboratory, University \\ of Liverpool; Crown Street, Liverpool L69 3BX, U.K.: ${ }^{d}$ Departamento de Fisiologia e Farmacologia, Universidade Federal \\ do Ceará; Campus do Porangabuçu, 60.451-970 Fortaleza-Ceará-Brasil: and e Departamento de Bioquímica e Biologia \\ Molecular, Universidade Federal do Ceará; Av Mister Hull s/n Bloco 907, 60.455-970, Fortaleza-Ceará-Brasil.
}

Received September 14, 2007; accepted January 13, 2008; published online January 21, 2008

Sulfated-polysaccharides are exploited as antithrombotic and anticoagulant agents and suggested to be immunostimulants. The sulfated-polysaccharide isolated from the red-marine-algae Champia feldmannii (Cf-PLS) was purified by ion exchange chromatography and tested in experimental protocols of coagulation, inflammation (in Wistar rats) and nociception (in Swiss mice). Cf-PLS was tested i.v. for its anti-inflammatory activity in the paw-edema induced by classical inflammatory stimuli and s.c. for its pro-inflammatory activity in the pawedema and peritonitis models. The anticoagulant activity was evaluated by the test of partial thromboplastin activation time (aPTT) and the antinociceptive effect in the writhing-test. Cf-PLS was not anti-inflammatory, but rather induced maximal edematogenic activity at $0.9 \mathrm{mg} / \mathrm{kg}(1.01 \pm 0.030 \times 0.06 \pm 0.03 \mathrm{ml})$ compared to controls $(0.06 \pm 0.03 \mathrm{ml})$, increased vascular-permeability $(38.44 \pm 12.63 \times 11.29 \pm 3.91 \mu \mathrm{g} / \mathrm{g})$ and stimulated neutrophil migration $(3.348 \pm 295 \times 307 \pm 99$ cells $/ \mu \mathrm{l}) \quad 1 \mathrm{~h}$ after injection. Cf-PLS was also antinociceptive $(6.6 \pm 1.28 \times 33 \pm 1.44$ writhes) and extended human plasma coagulation time by 3 times. Our data suggest that this molecule may be an important immunostimulant.

Key words sulfated-polysaccharide; Champia feldmannii; inflammation; nociception; coagulation; marine algae

Sulfated-polysaccharides are complex macromolecular constituents of the extracellular matrix of marine algae that play an important role in mechanical, osmotic and ionic regulation. ${ }^{1)}$ In Biomedicine the anticoagulant and antithrombotic properties have been most widely exploited and, at least for galactans, appear to be dependent on the sulfatation content and/or position of the sulfate groups. ${ }^{2)}$ A natural sulfated polymer of L-fucose (fucoidan) showed a dose-dependent inhibition of leukocyte migration in the in vivo peritonitis model ${ }^{3)}$ and sulfated fucans isolated from brown algae showed potent in vitro and in vivo inhibition of the human complement system. ${ }^{4,5)}$ It was demonstrated that a sulfatedpolysaccharide fraction extracted from the brown algae Porphyra haitanesis presents an in vivo antioxidant property, causing an increase in the spleen and thymus size, suggestive of an immunostimulant action. ${ }^{6)}$ Additionally, sulfated galactans of the red marine algae Bryothamnion seaforthii presented antinociceptive activity in mice ${ }^{7)}$ and of the red micro algae Pophyridium sp. anti-inflammatory action inhibiting eritema formation after topical use in humans. ${ }^{8)}$ However, studies of sulfated galactans role in models of inflammation in vivo are rare in the literature. Here we isolated and investigated the effects of a sulfated galactan from the red marine algae Champia feldmannii, widely encountered along the South East and North East Brazilian sea coast, in experimental models of acute inflammation, coagulation and nociception.

* To whom correspondence should be addressed. e-mail: assreuy@uece.br

\section{MATERIALS AND METHODS}

Animals Male Wistar rats $(150-250 \mathrm{~g})$ and Swiss mice $(25-35 \mathrm{~g})$ were maintained with a controlled $12 / 12 \mathrm{~h}$ light/dark cycle, at a temperature of $25^{\circ} \mathrm{C}$ with free access to food and water. The experimental protocols used in this study were approved by the Institutional Animal Care and Use Committee of the State University of Ceará (UECE), Fortaleza-CE, Brazil, in accordance with international guidelines (NIH publication No. 85-23, revised 1985).

Algae Champia feldmannii belongs to the order Rhodymeniales, family Lomentariaceae and was collected in the Pacheco beach of Caucaia, Ceará, Brazil. Algae were classified by Wladimir R. L. Farias, Department of Fishery Engeneering of Federal University of Ceará-Brazil.

Erythrocytes Human erythrocytes were obtained from healthy donors at the Hematology Center of the Federal University of Ceará-Brazil.

Drugs and Reagents Dextran sulphate, $\Lambda$-carrageenan, Evans blue, zymosan, morphine, cethylpiridinium chloride, sodium acetate, calcium chloride, ketamine, sulphuric acid, papain, 1-9-di-metylene blue (DMB), ethylenodiaminotetracetic acid (EDTA), indomethacin, dexamethasone, pentoxifylline, L- $N$-nitro-arginine methyl ester (L-NAME), meclyzine and formamide, $N$-acetyl- $N, N, N$-trimethylammonium bromide, 1,3-diaminopropane, toluidine blue, agarose gel (Sigma Chemical Co., St. Louis, MO, U.S.A. or SigmaAldrich Chemie, Steinheim, Germany); absolute ethanol, sodium chloride, sodium dodecyl sulfate (SDS) and 2-mer- 
captoethanol (Merck, Darmstadt, Germany); DEAE-cellulose (Amersham Biosciense, Upsala, Sweden); heparin (Cristália Produtos Químicos e Farmaceuticos, São Paulo, Brazil); acetic acid (Vetec Química Farm. Ltda, São Paulo, Brazil); bovine serum albumin-fraction V (Pierce, Rockford, U.S.A.); activated cephalin (Celite Biolab, Mérieux, France); cystein (Alfagene, Carcavelos, Portugal).

Sulfated-Polysaccharide Extraction The algae were cleaned, dehydrated and cut into small pieces. Two grams of dry tissue was re-hydrated with $100 \mathrm{ml}$ of $0.1 \mathrm{M}$ sodium acetate buffer, pH 5.0 containing $5 \mathrm{~mm}$ EDTA and $5 \mathrm{~mm}$ cystein and incubated for $24 \mathrm{~h}$ with papain $(30 \mathrm{mg} / \mathrm{ml})$ at $60^{\circ} \mathrm{C}$ before centrifugation $\left(8000 \times \boldsymbol{g} ; 20 \mathrm{~min} ; 4^{\circ} \mathrm{C}\right)$. The sulfatedpolysaccharide from the supernatant was precipitated with $6.4 \mathrm{ml}$ of $10 \%$ cetylpiridinium chloride (CPC) at room temperature (r.t.) for $24 \mathrm{~h}$. After new centrifugation, the pellet was washed with $200 \mathrm{ml}$ of $0.05 \% \mathrm{CPC}$, dissolved in a mixture of $70 \mathrm{ml}$ of $2 \mathrm{M} \mathrm{NaCl}$ : absolute ethanol $(100: 15 ; \mathrm{v}: \mathrm{v})$ and the sulfated-polysaccharide precipitated again by addition of $122 \mathrm{ml}$ of absolute ethanol for $24 \mathrm{~h}$ at $4{ }^{\circ} \mathrm{C}$. The pellet was collected by centrifugation, washed twice with $200 \mathrm{ml}$ of $80 \%$ ethanol, and once with $122 \mathrm{ml}$ of absolute ethanol, and dried at $60^{\circ} \mathrm{C}$ overnight.

Ion Exchange Chromatography The isolation and purification protocols used were based on previous published articles of our group., ${ }^{2,9)}$ Briefly, $1 \mathrm{ml}$ of the crude extract, containing $1 \mathrm{mg}$ of total sulfated-polysaccharide was applied to an ion exchange chromatograpy (DEAE-cellulose), equilibrated with the extraction buffer at $1 \mathrm{ml} / \mathrm{min}$. Elution was performed by a step wise gradient of $0.5-1.6 \mathrm{M} \mathrm{NaCl}$ in the equilibrium buffer. Fractions were monitored for the presence of sulfate groups by metachromatic activity (A525 nm) with 1-9-dimethylmethylene (DMB), total carbohydrate content by the DuBois method at $490 \mathrm{~nm}^{10)}$ and salt concentration analyzed by conductivity (Analyserc-650, conductivimeter). The $1.2 \mathrm{M}$ fraction of the purified sulfated-polysaccharide from $C$. feldimannii (Cf-PLS) was solubilized in $0.15 \mathrm{M}$ sterile $\mathrm{NaCl}$ (saline) and filtered through a Membrane Low Protein Binding Non-Pyrogenic $(0.45 \mathrm{~mm}$; ref: 4184 Acrodisc $^{\circledR}$ ) before biological assays.

Agarose Gel Electrophoresis Sulfated-polysaccharides were analyzed by agarose gel electrophoresis: $10 \mu \mathrm{l}$ of crude extract (total sulfated-polysaccharide) and $1.2 \mathrm{~m}$ DEAE-celulose fraction (Cf-PLS) solutions $\left(5 \mathrm{mg} \cdot \mathrm{1}^{-1}\right)$ were applied to a $0.5 \%$ agarose gel in $50 \mathrm{~mm} 1,3$-diaminopropane/acetate buffer $(\mathrm{pH} 9.0)$ and run at $110 \mathrm{~V}$ for $1 \mathrm{~h}$. The gel was fixed with $0.1 \% \mathrm{~N}$-acetyl- $N, N, N$-trimethylammonium bromide solution for $24 \mathrm{~h}$, dried, stained with $0.1 \%$ toluidine blue in $80 \%$ absolute ethanol and discoloured with $1 \%$ acetic acid : absolute ethanol $(1: 1)$.

Evaluation of Cf-PLS Anticoagulant Activity by the Test of Partial Thromboplastin Activation Time Plasma poor in platelets were obtained from citrated $(0.9 \%)$ human blood of five healthy donors. Normal human plasma $(50 \mu \mathrm{l})$ was incubated with $5 \mu \mathrm{l}$ of Cf-PLS for $1 \mathrm{~min}$ at $37^{\circ} \mathrm{C}$. Then $50 \mu \mathrm{l}$ of activated cephalin were added and incubated at $37^{\circ} \mathrm{C}$ for more $2 \mathrm{~min}$. Following this, $50 \mu \mathrm{l}$ calcium chloride $(0.025 \mathrm{M})$ was added and the coagulation time registered in a coagulometer (Drake-Quick Timer). Heparin (193 IU/mg) was used as a standard.

Cf-PLS Activity in Experimental Models of Inflamma- tion in Rats 1. Paw-Edema: Paw volume was measured immediately before subcutaneous (s.c.) injection of inflammatory stimuli (zero time) into the hind paw of rats $(n=5$ 8 ) under light ether anesthesia ${ }^{11)}$ and at selected time intervals $(1 / 2,1,2,3,4,8,24,48 \mathrm{~h})$ thereafter using a hydroplethysmometer (PanLab, Barcelona-Spain). Results were expressed as the increase or reduction in paw volume $(\mathrm{ml})$ calculated by subtracting the basal volume measured at zero time. The area under the time-course curve $(A U C)$ was calculated using a trapezoidal rule and results expressed in arbitrary units. ${ }^{12)}$

Anti-inflammatory activity: Dextran $(300 \mu \mathrm{g} / \mathrm{paw})$, carrageenan $(2 \mathrm{mg} / \mathrm{paw})$, and zymosan $(1 \mathrm{mg} / \mathrm{paw})$, inducers of osmotic edema, cell infiltrate and activation of complement cascade, ${ }^{13,14)}$ were injected s.c. into animal paws $(0.1 \mathrm{ml} /$ $100 \mathrm{~g}$ body weight). Cf-PLS was injected intravenously (i.v.) at different times, previously or concomitant to injection of the inflammatory stimuli $(0.1-0.9 \mathrm{mg} / \mathrm{kg})$. Positive controls received the flogistic agents and negative controls, the same volume of sterile saline. Edema was measured at 1/2, 1, 2, until $4 \mathrm{~h}$ after inflammatory stimuli.

Pro-inflammatory activity: a) Paw-edema: induced by subcutaneously (s.c.) injection of Cf-PLS at the doses of $0.1,0.3$ and $0.9 \mathrm{mg} / \mathrm{kg}(0.1 \mathrm{ml} / 100 \mathrm{~g}$ of body weight). Control animals received the same volume of sterile saline. Edema was measured at 1/2, 1, 2, 3, 4, 24 and $48 \mathrm{~h}$ after stimuli; b) Vascular permeability: simultaneously with Cf-PLS injection, animals received Evans blue $(25 \mathrm{mg} / \mathrm{kg}$; i.v.) and were sacrificed $1 \mathrm{~h}$ later, at the edema peak. Paws were sectioned at the ankle, weighed, placed in $4 \mathrm{ml}$ formamide and incubated at $36^{\circ} \mathrm{C}$ for $72 \mathrm{~h}$. The optical density of the extracted dye was estimated at $600 \mathrm{~nm}$ and results presented as $\mu \mathrm{g}$ of Evans blue/mg of tissue based on a control Evans blue curve ${ }^{15)} ; \mathrm{c}$ ) Pharmacological modulation: Cf-PLS was injected s.c. (0.9 $\mathrm{mg} / \mathrm{kg}$ ) into animal paws $30 \mathrm{~min}$ or $1 \mathrm{~h}$ after treatment with: meclyzine $(30 \mathrm{mg} / \mathrm{kg}$; s.c.; $30 \mathrm{~min}$.); indomethacin $(5 \mathrm{mg} / \mathrm{kg}$; s.c.; $1 \mathrm{~h})$; dexamethasone $(1 \mathrm{mg} / \mathrm{kg}$, s.c.; $1 \mathrm{~h})$; pentoxifylline $(90 \mathrm{mg} / \mathrm{kg}$; s.c.; $1 \mathrm{~h})$ and L-NAME $(25 \mathrm{mg} / \mathrm{kg}$; i.v.; $1 \mathrm{~h}){ }^{16,17)}$

2. Peritonitis Model: Pro-inflammatory Activity: C. feldmannii $(0.9 \mathrm{mg} / \mathrm{kg})$ or saline were injected intraperitoneally ( $1 \mathrm{ml}$; i.p.) into animals $(n=6)$. After $1 \mathrm{~h}$ (at the edema peak), animals were killed and cells harvested by washing peritoneal cavities with $10 \mathrm{ml}$ saline (5 IU heparin). Total and differential (neutrophils, eosinophils, mast cells and mononuclear) cell counts were performed. ${ }^{18)}$ Results were expressed as number of leukocytes per $\mu \mathrm{l}$ of peritoneal wash.

Cf-PLS Activity in the Acetic Acid-Induced Writhing Test in Mice Mice ( $8-10$ per group) were injected i.p. with $0.6 \%$ acetic acid $(0.1 \mathrm{ml} / 10 \mathrm{~g}$ body weight $)$ and after $10 \mathrm{~min}$, the number of constrictions was registered for 20 min. ${ }^{19)}$ Animals were treated i.v. with $C$. feldimannii at the doses of $0.2,1,5$ and $25 \mathrm{mg}(0.1 \mathrm{ml} / 10 \mathrm{~g}$ body weight), $30 \mathrm{~min}$ before acetic acid administration. Control animals were injected with a similar volume of sterile saline.

Acute Toxicity Assay Cf-PLS (1, 5, $25 \mathrm{mg} / \mathrm{kg}$ ) or saline were injected i.v. into groups of 10 mice. Animals were maintained with free access of water and food and observed during $48 \mathrm{~h}$ for time of surveillance, abnormal pattern of behavior (piloerection, tachycardia, cyanosis, tachypnea, pruritus, convulsions, sedation and death).

Statistical Analysis The data are presented as mean \pm 
S.E.M. of $n$ animals per group and statistical differences were analyzed using ANOVA followed by a Duncan test for the edema and peritonitis models and by Student-NewmanKeuls method for the writhing test. Statistical significance was set at $p<0.05$.

\section{RESULTS AND DISCUSSION}

The crude extract of Champia feldmannii exhibited a high content of sulfated-polysaccharide $(36.2 \%)$, with superior yield to that from the red algae Gracilaria cornea $(21.4 \%){ }^{20)}$ The total sulfated-polysaccharide isolated from C. feldmannii (Cf-PLS), by ion-exchange chromatography, revealed a fraction with high metachromatic activity (fraction no. 30), that was eluted at $1.2 \mathrm{~m} \mathrm{NaCl}$. The carbohydrate content of collected fractions (elution from $0.7 \mathrm{M}$ to $1.2 \mathrm{M}$ ) was similarly high, except for the fraction eluted at $1.6 \mathrm{~m}$ (no. 40) (Fig. 1a). The electrophoretic pattern of Cf-PLS (Fig. 1b) showed a more homogeneous band than the polydispersed band of total sulfated-polysaccharide. Fraction no. 30, with the highest metachromatic activity, also showed maximal anticoagulant effect, presenting a delay in the coagulation time around 3 times higher $(114.0 \mathrm{~s})$ than the normal partial thromboplastin activation time (Table 1). The remained fractions presented low anticoagulant activity with a delay of the coagulation time varying from the normal $(37.5 \mathrm{~s})$ and between 1 to 2 times higher.

Table 2 shows that s.c. administration of carrageenan $(2 \mathrm{mg})$, dextran $(300 \mu \mathrm{g})$ and zymosan $(1 \mathrm{mg})$ evoked a tem-

Table 1. Anticoagulant Activity of the Sulfated Polysaccharide from $C$. feldmannii

\begin{tabular}{ccc}
\hline \hline Fraction $(\mathrm{M})^{a)}$ & Coagulation time $(\mathrm{s})$ & $\operatorname{aPTT}\left(T_{1} / T_{0}\right)$ \\
\hline 0.7 & 58.1 & 1.6 \\
0.9 & 41.6 & 1.1 \\
1.2 & 114.0 & 3.0 \\
1.4 & 24.3 & 0.7
\end{tabular}

a) Incubation of $50 \mu 1$ human plasma $+5 \mu 1 \mathrm{PLS} / 1 \mathrm{~min} / 37^{\circ} \mathrm{C}$, plus $50 \mu 1$ activated cephaline for more $2 \mathrm{~min}$ before addition of $50 \mu \mathrm{CaCl}_{2}(0.025 \mathrm{M})$. Coagulation time registered using a coagulometer (Drake-Quick Timer). aPTT $=$ thromboplastin partial activating time. poral course of edema, with respective peaks after $4 \mathrm{~h}(0.83 \pm$ $0.06), 30 \mathrm{~min}(0.83 \pm 0.04)$ and $30 \mathrm{~min}(1.06 \pm 0.05 \mathrm{ml})$ of injection, compared to saline group at $30 \mathrm{~min}(0.05 \pm 0.03 \mathrm{ml})$. Cf-PLS injected i.v. in all doses and scheme of treatment did not inhibit the edema evoked by these stimuli of diverse inflammatory mechanisms. This data is in accordance with the literature that correlates anti-inflammatory effects with sulfated fucans but not with sulfated galactans. ${ }^{3-5)}$ On the other hand, Cf-PLS potentiated the edema at some scheme of treatment (Table 2). Cf-PLS at $0.9 \mathrm{mg} / \mathrm{kg}$ increased the carrageenan-evoked edema from $0.48 \pm 0.04$ to $0.82 \pm 0.06 \mathrm{ml}$ (co-injected with carrageenan) and to $0.8 \pm 0.12 \mathrm{ml}$ (injected $10 \mathrm{~min}$ prior carrageenan), $2 \mathrm{~h}$ after development. Again, treatment with Cf-PLS at $0.1 \mathrm{mg} / \mathrm{kg}, 30 \mathrm{~min}$ before dextran, increased the edema induced by this agent from $0.71 \pm 0.03$ to $0.9 \pm 0.05 \mathrm{ml}$ after $1 \mathrm{~h}$ and from $0.33 \pm 0.04$ to $0.57 \pm 0.08$ after $4 \mathrm{~h}$ of challenge. At this time, Cf-PLS at $0.3 \mathrm{mg} / \mathrm{kg}$ enhanced the edema from $0.33 \pm 0.04$ to $0.52 \pm 0.06 \mathrm{ml}$. Simultaneous treatment of Cf-PLS $(0.9 \mathrm{mg} / \mathrm{kg})$ with zymosan also enhanced the edema formation from $0.92 \pm 0.03$ to $1.02 \pm$ $0.02 \mathrm{ml}$ after $2 \mathrm{~h}$.

Due to the potentiator effect elicited by the i.v. injection of Cf-PLS upon the paw edema induced by classical inflammatory stimuli, the pro-inflammatory effect was tested by its local (s.c.) injection in the models of paw edema and peritonitis. Cf-PLS induced an intense edema, evaluated during $4 \mathrm{~h}$, at all doses tested $(0.1,0.3,0.9 \mathrm{mg} / \mathrm{kg})$, showing maximal activity at the highest dose $(102.25 \pm 2.31)$ compared to saline group (25.5 \pm 8.46 arbitrary units) (Fig. 2a). Cf-PLS at $0.9 \mathrm{mg} / \mathrm{kg}$ induced a long lasting and significant edema until $12 \mathrm{~h}$ with a peak of activity at the 1 st hour after administration $(1.01 \pm 0.03 \mathrm{ml})$ compared to saline $(0.06 \pm 0.03 \mathrm{ml})$. Besides, only after $24 \mathrm{~h}$ the values returned to basal (Fig. 2b), a typical feature of acute inflammatory processes. Additionally, Cf-PLS $(0.9 \mathrm{mg} / \mathrm{kg})$ injected s.c. into rat paws, significantly increased vascular permeability $(38.44 \pm 12.63 \mu \mathrm{g} / \mathrm{mg})$ compared to controls $(11.29 \pm 3.91 \mu \mathrm{g} / \mathrm{mg}) 1 \mathrm{~h}$ after administration, at the edema peak (Fig. 2c). This set of data clearly demonstrates that Cf-PLS is able to activate a vascular event of the inflammatory process. Accordingly, neutrophil accumulation in the inflamed tissue contributes to vascular in- a)

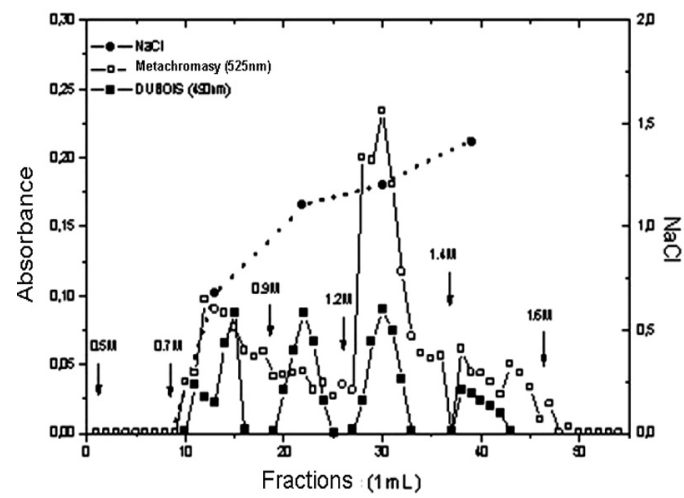

b)

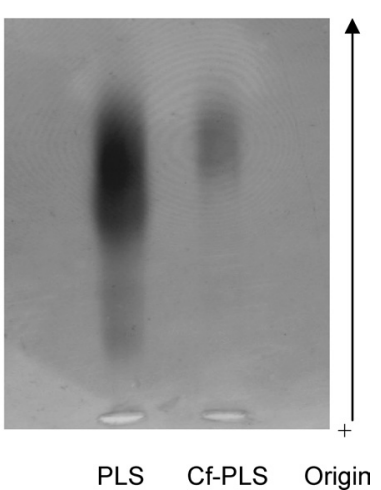

Fig. 1. Isolation and Characterization of a Sulfated-Polysaccharide from C. feldmannii

(a) Ion exchange chromatography. Crude extract $(1 \mathrm{mg} / \mathrm{ml})$ applied to a DEAE-cellulose column $(1.5 \times 6.5 \mathrm{~cm})$, equilibrated with $0.1 \mathrm{M}$ sodium acetate buffer $\mathrm{pH} 5.0+5 \mathrm{~mm}$ EDTA $+5 \mathrm{~mm}$ cystein at $1 \mathrm{ml} / \mathrm{min}$. Elution in the same buffer at $\mathrm{NaCl}(0.5,0.7,0.9,1.2,1.4,1.6 \mathrm{M})$. Metachromatic activity monitored by $1,9-$ dimetylene blue $($ A 525$)$ and carbohydrate content by Dubois (A490 nm); (b) agarose gel electrophoresis. Total sulfated-polysaccharide (PLS; $10 \mu \mathrm{l})$ and Cf-PLS $\left(5 \mathrm{mg} \cdot \mathrm{1}^{-1}\right.$ ) applied to $0.5 \%$ agarose gel in $50 \mathrm{~mm} 1,3-$ diaminopropane/acetate buffer (pH 9.0); $110 \mathrm{~V} ; 1 \mathrm{~h}$. Gel fixed with $0.1 \% N$-acetyl- $N, N, N$-trimethylammonium bromide solution for $24 \mathrm{~h}$, dried, stained with $0.1 \%$ toluidine blue in $80 \%$ absolute ethanol and discoloured with $1 \%$ acetic acid : absolute ethanol $(1: 1)$. 
Table 2. Sulfated-Polysaccharide from C. feldmannii Is Not Anti-inflammatory But Potentiates the Rat Paw Edema Evoked by Dextran, Carrageenan and Zymosan

\begin{tabular}{|c|c|c|c|c|c|c|}
\hline \multirow{2}{*}{$\begin{array}{l}\text { Time and dose } \\
\text { of PLS } \\
\text { pre-treatment }{ }^{a)}\end{array}$} & \multirow{2}{*}{$\begin{array}{l}\text { Experimental } \\
\text { groups }\end{array}$} & \multicolumn{5}{|c|}{ Paw edema evaluation (h) } \\
\hline & & 0.5 & 1 & 2 & 3 & 4 \\
\hline & Saline ${ }^{b)}$ & $0.05 \pm 0.03$ & $0.05 \pm 0.02$ & $0.01 \pm 0.01$ & zero & zero \\
\hline & $\mathrm{Cg}^{c)} 2 \mathrm{mg} / \mathrm{paw}$ & $0.38 \pm 0.01 *$ & $0.45 \pm 0.04 *$ & $0.48 \pm 0.04 *$ & $0.63 \pm 0.05^{*}$ & $0.83 \pm 0.06^{*}$ \\
\hline $\begin{array}{l}\text { Simultaneous } \\
(0.9 \mathrm{mg} / \mathrm{kg})\end{array}$ & $\mathrm{Cg}+\mathrm{PLS}$ & $0.34 \pm 0.09$ & $0.46 \pm 0.04$ & $0.82 \pm 0.06^{* *}$ & $0.88 \pm 0.01$ & $1.08 \pm 0.14$ \\
\hline 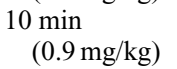 & $\mathrm{Cg}+\mathrm{PLS}$ & $0.54 \pm 0.11$ & $0.62 \pm 0.09$ & $0.80 \pm 0.12^{* *}$ & $0.84 \pm 0.15$ & $0.94 \pm 0.14$ \\
\hline \multirow{2}{*}{ 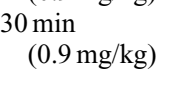 } & $\mathrm{Cg}+\mathrm{PLS}$ & $0.20 \pm 0.00$ & $0.50 \pm 0.00$ & $0.60 \pm 0.02$ & $0.80 \pm 0.04$ & $0.83 \pm 0.04$ \\
\hline & $\operatorname{Dex}^{c)} 300 \mu \mathrm{g} / \mathrm{paw}$ & $0.83 \pm 0.04 *$ & $0.71 \pm 0.03 *$ & $0.52 \pm 0.03 *$ & $0.41 \pm 0.05^{*}$ & $0.33 \pm 0.04 *$ \\
\hline $\begin{array}{l}30 \mathrm{~min} \\
\quad(0.1 \mathrm{mg} / \mathrm{kg})\end{array}$ & PLS+Dex & $1.00 \pm 0.10$ & $0.90 \pm 0.05^{* *}$ & $0.67 \pm 0.08$ & $0.57 \pm 0.08$ & $0.57 \pm 0.08^{* *}$ \\
\hline $\begin{array}{l}30 \mathrm{~min} \\
\quad(0.3 \mathrm{mg} / \mathrm{kg})\end{array}$ & PLS+Dex & $0.92 \pm 0.11$ & $0.86 \pm 0.07$ & $0.60 \pm 0.03$ & $0.52 \pm 0.06$ & $0.52 \pm 0.06^{* *}$ \\
\hline \multirow{2}{*}{$\begin{array}{l}30 \mathrm{~min} \\
\quad(0.9 \mathrm{mg} / \mathrm{kg})\end{array}$} & PLS+Dex & $0.75 \pm 0.06$ & $0.71 \pm 0.01$ & $0.60 \pm 0.02$ & $0.41 \pm 0.04$ & $0.43 \pm 0.04$ \\
\hline & $\mathrm{Zy}^{c)}(1 \mathrm{mg} /$ pata $)$ & $1.06 \pm 0.05^{*}$ & $1.03 \pm 0.06^{*}$ & $0.92 \pm 0.03^{*}$ & $0.92 \pm 0.03^{*}$ & $0.96 \pm 0.02 *$ \\
\hline $\begin{array}{l}\text { Simultaneous } \\
(0.9 \mathrm{mg} / \mathrm{kg})\end{array}$ & $\mathrm{PLS}+\mathrm{Zy}$ & $1.21 \pm 0,05$ & $1.32 \pm 0.03$ & $1.02 \pm 0.02 * *$ & $1.00 \pm 0.00$ & $0.90 \pm 0.03$ \\
\hline
\end{tabular}

a) Sulfated-polysaccharide (PLS) was injected i.v. $(0.1-0.9 \mathrm{mg} / \mathrm{kg})$ at different times, previously or simultaneously to injection of inflammatory stimuli. $b)$ Saline injected s.c. as negative control. c) Carrageenan (Cg), dextran (Dex) and zymosan (Zy) injected s.c. as positive controls simultaneously or at different times after PLS. Results calculated as increase or reduction in paw volume $(\mathrm{ml})$ and expressed as mean \pm S.E.M. $(n=5-8)$; ANOVA and Duncan test; $* p<0.05$ versus saline; $* * p<0.05$ versus respective positive controls.

a)

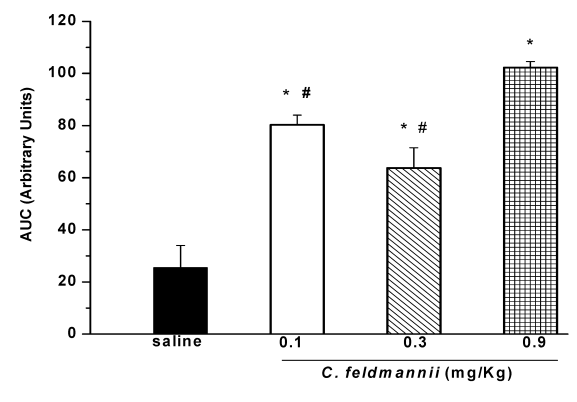

b)

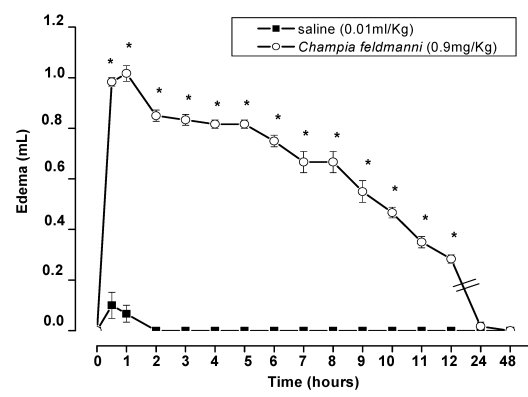

c)

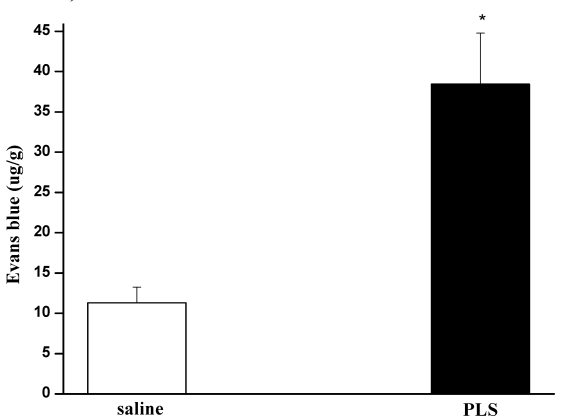

Fig. 2. Cf-PLS Induces Acute Paw-Edema and Increases Vascular Permeability

Rats were treated s.c. with PLS $(0.1,0.3$ or $0.9 \mathrm{mg} / \mathrm{kg}$ ) or sterile saline. Edema was measured before (time zero) and at $1 / 2,1,2,3,4,24$ and $48 \mathrm{~h}$ after stimuli and expressed as (a) $A U C$ (during $4 \mathrm{~h}$ ) in arbitrary units; (b) increase in paw volume ( $\mathrm{ml})$ subtracted from zero time; (c) vascular permeability ( $\mu \mathrm{g}$ of Evans blue/g paw wet weight). Simultaneously to Cf-PLS injection, animals received Evans blue $(25 \mathrm{mg} / \mathrm{kg}$; i.v.) and were sacrificed $1 \mathrm{~h}$ later. Mean \pm S.E.M. $(n=5-8) ; * p<0.05$ versus saline; $\# p<0.05$ versus $C$. feldmannii $(0.9 \mathrm{mg} / \mathrm{kg})$.

flammatory events such as increase in vascular permeability with protein exudation and vice-vers $a^{21,22)}$ Based on this, CfPLS was tested in the model of peritonitis in order to investigate possible alterations in the leukocyte chemotaxy. In this model, i.p. administration of Cf-PLS $(0.9 \mathrm{mg} / \mathrm{kg})$ significantly increased the leukocyte count in the rat peritoneal cavities $(4.167 \pm 367$ cells $/ \mu \mathrm{l})$ at the edema peak compared to the control $(2.031 \pm 133$ cells $/ \mu \mathrm{l})$. The Cf-PLS increase in leukocyte number was accompanied by neutrophil migration $(3.348 \pm 295$ cells $/ \mu \mathrm{l})$, around 11 times higher than controls $(307 \pm 99$ cells $/ \mu 1)$ (Fig. 3). In fact, neutrophils are the cells commonly encountered in inflammatory exsudato in the initial $24 \mathrm{~h}$ of inflammation. This result reinforces that obtained in the paw-edema model showing that the Cf-PLS pro-inflammatory effect presents a profile of the acute phase inflammatory response. The pro-inflammatory effect elicited by Cf-PLS is in line with literature that demonstrated an immunostimulant activity of the species of juvenile prawn Litopenaeus vannamei after immersion in a solution rich in sulfated-polysaccharide from the microalgae Cyanotheca $\mathrm{sp}^{23}$ ) Besides, carrageenan, a sulfated polysaccharide from marine red algae, is classically used as a positive control in experimental models of inflammation because its pro-inflammatory events, that involve cell migration and participation of a diversity of mediators. ${ }^{24)}$ In addition, it was demonstrated that a sulfated-polysaccharide fraction from the brown algae Porphyra haitanesis shows in vivo antioxidant property and increases the spleen and thymus size. ${ }^{6)}$ We further observed that the edema induced by Cf-PLS at 0.9 $\mathrm{mg} / \mathrm{kg}$ was inhibited in animals pre-treated with meclyzine, dexamethasone, indomethacin, and pentoxifylline by 5,15 , $25,29 \%$, respectively, but not with L-NAME (data not shown). Dexamethasone is a synthetic glucocorticoide with potent antiinflammatory and immunosuppressant properties; indomethacin is a non-specific inhibitor of the cyclooxygenase enzyme activity and prostaglandins synthesis ${ }^{25)}$; LNAME, non-specifically, inhibits the activity of nitric oxide synthase isoforms and nitric oxide (NO) production ${ }^{26}$; pen- 


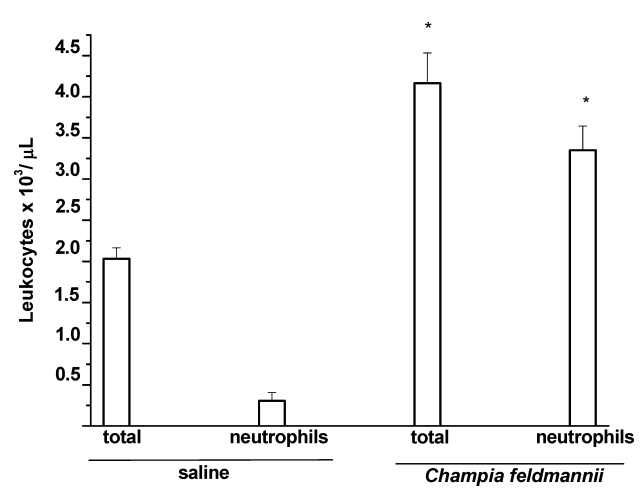

Fig. 3. Cf-PLS Induces Neutrophil Migration into Peritoneal Cavities

Rats $(n=6)$ received $1 \mathrm{ml}$ of Cf-PLS $(0.9 \mathrm{mg} / \mathrm{kg}$; i.p.) or sterile saline. After $1 \mathrm{~h}$ peritoneal fluid was collected for differential leukocyte counts. Results expressed as mean \pm S.E.M. of no. of cells $/ \mu$ l. $* p<0.05$ compared to respective negative controls injected with saline.

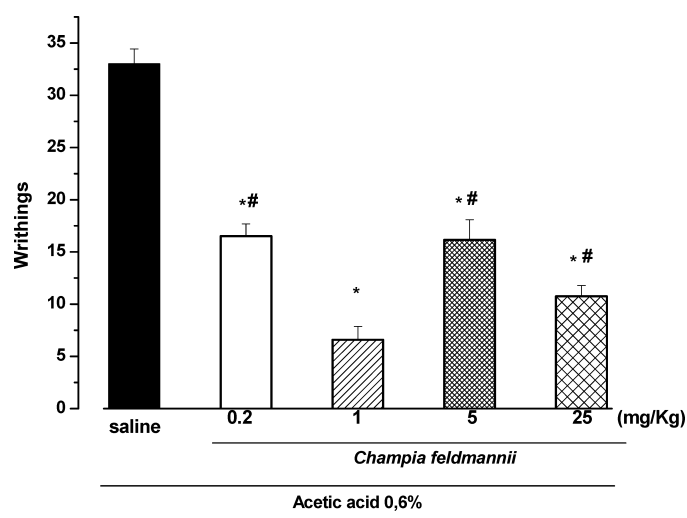

Fig. 4. Cf-PLS Presents Antinociceptive Effect in the Writhing Test in Mice

Cf-PLS $(0.2,1,5,25 \mathrm{mg} / \mathrm{kg})$ or saline were injected i.v. $30 \mathrm{~min}$ before $0.6 \%$ acetic acid i.p. After $10 \mathrm{~min}$ the no. of abdominal constrictions was counted during $20 \mathrm{~min}$. Results expressed as mean \pm S.E.M. Student-Newman-Keuls method. $* p<0.05$ compared to acetic acid; $\# p<0.05$ compared to $C$. feldmannii $(1 \mathrm{mg} / \mathrm{kg}) ; n=8-10$.

toxifylline inhibits production of interleukin-1 (IL-1) and tumoral necrosis factor- $\alpha$ (TNF- $\alpha$ ) that participates in various events of the inflammatory response, including expression of adhesion molecules ${ }^{27,28)}$ and meclyzine, ${ }^{15)}$ an inhibitor of histamine- $\mathrm{H}_{1}$ receptors. These results reinforce the Cf-PLS proinflammatory effect, excluding possible endotoxin contamination and suggest the involvement of primary cytokines, prostaglandins and histamine in this effect.

Although exhibiting a pro-inflammatory action, the i.v. treatment with Cf-PLS $(0.2,1,5,25 \mathrm{mg} / \mathrm{kg}), 30 \mathrm{~min}$ before i.p. administration of $0.6 \%$ acetic acid, caused an antinociceptive effect, reducing the number of abdominal constrictions in mice at all doses. The maximal activity was observed at $1 \mathrm{mg} / \mathrm{kg}(6.6 \pm 1.28)$ about an $80 \%$ reduction from control values (33 \pm 1.44$)$ (Fig. 4). A similar effect was seen for sulfated galactans isolated from the red marine algae Bryothamnion seaforthii. ${ }^{7)}$ This apparently conflicting data may be explained by the well known fact that opioid-like drugs such as morphine are potent analgesics, despite of a lack of antiinflammatory activity. Additionally, animals injected with CfPLS up to the dose of $30 \mathrm{mg} / \mathrm{kg}$, observed during $48 \mathrm{~h}$, did not present any signs of toxicity (data not shown).

In conclusion, our study has shown that the sulfated-polysaccharide from the red marine algae Champia feldmannii possesses interesting anticoagulant, pro-inflammatory and antinociceptive properties. The potential underlying mechanisms involved in these activities are currently being evaluated and form the basis of an on-going study. Our current results suggest that these molecules may be important tools for the study of inflammatory processes associated with nociception and thrombus formation, and potentially useful in clinical situations in which activation of the immune system is necessary.

Acknowledgments Funding: Conselho Nacional de Desenvolvimento Cientifico e Tecnológico-CNPq, Fundação Cearense de Amparo a Pesquisa-FUNCAP and Coordenação de Aperfeiçoamento de Pessoal de Nível Superior-CAPES. Assreuy, AMS; Sampaio, AH; Cavada, BS and Alencar, NM are senior investigators of $\mathrm{CNPq} /$ Brazil.

\section{REFERENCES}

1) Kloareg B., Quatrano R. S., Oceanogr. Mar. Biol. Annu. Rev., 26, 259-315 (1998)

2) Farias W. R. L., Valente A. P., Pereira M. S., Mourão P. A. S., J. Biol. Chem., 275, 29299-29307 (2000).

3) Preobrazhenskaya M. E., Berman A. E., Mikhailov V. I., Ushakova N A., Mazurov A. V., Semenov A. V., Usov A. I., Nifant'ev N. E., Bovin N. V., Biochem. Mol. Biol. Int., 43, 443 - 451 (1997).

4) Blondin C., Fisher E., Boisson-Vidal C., Kazatchkine M., Jozefonvicz J., Mol. Immunol., 31, 247-253 (1994).

5) Tissot B., Montdargent B., Chevolot L., Varenne A., Descroix S., Gareil P., Daniel R., Biochim. Biophys. Acta, 1651, 5-16 (2003).

6) Zhang Q., Li N., Zhou G., Lu X., Xu Z., Li Z., Pharmacol. Res., 48, $151-155$ (2003).

7) Viana G. S. B., Freitas A. L. P., Lima M. M. L., Vieira L. A., Andrade M. C., Benevides N. M., Braz. J. Med. Biol. Res., 35, 713-722 (2002).

8) Matsui S. M., Muizzudin N., Arad S., Marenus K., Appl. Biochem. Biotech., 104, 13-22 (2003).

9) Farias W. R., Nazareth R. A., Mourão P. A., Thromb. Haemost., 86, $1540-1546$ (2001).

10) Dubois M., Gilles K. A., Hamilton J. K., Rebers P. A., Smith F., Anal. Chem., 28, 350-356 (2003).

11) Cirino G., Peers S. H., Flower R. J., Browning J. L., Pepinsky R. B. Proc. Natl. Acad. Sci. U.S.A., 86, 3428-3432 (1989),

12) Landucci E. C. T., Antunes E., Donato J. L., Faro R., Hyslop S., Marangoni S., Oliveira B., Cirino G., De Nucci G., J. Pharmacol. 114, 578-583 (1995).

13) Lo T. N., Almeida A. P., Beaven M. A., J. Pharmacol. Exp. Ther., 221, 261-267 (1982).

14) Damas J., Prunesco P., Arch. Int. Pharmacodyn. Ther., 322, 115-123 (1990).

15) Wilhelm D. L., Pharmacol. Rev., 14, 251-280 (1962).

16) Feitosa R. F., Melciades G. B., Assreuy A. M. S., Rocha M. F., Ribeiro R. A., Lima A. A., Mediat. Inflamm., 11, 155-163 (2002).

17) Cuzzocrea S., Zingarelli B., Calapai G., Nava F., Caputi A. P., Life Sci., 60, 215-220 (1997)

18) Souza G. E. P., Ferreira S. H., Agents Actions, 17, $1-5$ (1985).

19) Koster R., Anderson M., De Beer E. J., Fed. Proc., 18, 412 (1959).

20) Melo M. R. S., Feitosa J. P. A., Freitas A. L. P., De Paula R. C. M., Carbohyd. Polym., 49, 491-498 (2002).

21) Issekutz A. C., Lab. Invest., 50, 605-607 (1984).

22) Wedmore C. V., Williams T. J., Nature (London), 289, 646-650 (1981).

23) Campa-Córdova A. I., Hernández-Saavedra N. I., De Philippis R., Ascencio F., Fish Shellfish Immun., 12, 353-366 (2002).

24) Di Rosa M., Giroud J. P., Willoughby D. A., J. Pathol., 104, 15-29 (1971).

25) Kankuri E., Vaali K., Korpela R., Pakari I., Vapatalo H., Moilanen E., Inflammation, 25, 301-310 (2001).

26) Moncada S., Palmer R. M. J., Higgs A., Pharmacol. Rev., 43, 109 142 (1991).

27) Bernot D., Peiretti F., Canalt M., Juhan-Vague I., Nalbone G., J. Cell. Physiol., 202, 434-441 (2005).

28) Dinarello C. A., Clin. Exp. Rheumatol., 20, 1-13 (2002). 